\title{
EFFECTIVE FLOW CONTROL AROUND A CIRCULAR CYLINDER BY USING BOTH A SPLITTER PLATE AND PLASMA ACTUATORS AS PASSIVE AND ACTIVE CONTROL METHODS
}

\author{
Hürrem AKBIYIK* and Yahya Erkan AKANSU** \\ *Çukurova University, Mechanical Engineering Department 01330, Adana, \\ hakbiyik@cu.edu.tr, ORCID: 0000-0002-1880-052X \\ ** Niğde Ömer Halisdemir University, Mechanical Engineering Department 51240, Niğde, \\ akansu@ohu.edu.tr, ORCID: 0000-0003-0691-3225
}

(Geliş Tarihi: 26.08.2020, Kabul Tarihi: 02.03.2021)

\begin{abstract}
In this study, passive and active flow control methods were used together to manipulate the flow around a circular cylinder. The experiments were conducted in a wind tunnel for the Reynolds number range of 4000 and 10000 based on the diameter of the circular cylinder (D). A splitter plate was used as passive flow control device and its length was chosen to be about 3.75D. Plasma actuators were placed on the circular cylinder at a position of $\pm 90^{\circ}$ as an active flow control device. Combining the active and passive flow control methods, a greater reduction of the drag coefficient was achieved compared to that of the cases when using these methods separately. For Reynolds numbers of 5000 and 10000 , the hybrid method gives a reduction in drag of $48 \%$ and $45 \%$, respectively. The velocity measurements were carried out by using the hot-wire anemometry and velocity profiles were obtained in the wake region. The flow was visualized by using a smoke wire method. The results revealed that the wake region of the circular cylinder with plasma actuator and splitter plate has a narrower width than the plain cylinder and with splitter plate. Also, it can be seen from spectral analysis that the vortex shedding frequency was suppressed significantly by usage of the hybrid flow control method was used.
\end{abstract}

Keywords: Circular cylinder, Plasma actuator, Splitter plate, Hybrid flow control, Vortex shedding frequency.

\section{PASİF VE AKTIF KONTROL YÖNTEMLERI OLARAK HEM BİR AYIRICI PLAKA HEMDE PLAZMA AKTÜATÖRLER KULLANILMASIYLA DAİRESEL BİR SİLINDİR ETRAFINDA ETKIILİ AKIŞ KONTROLÜNÜN SAĞLANMASI}

Özet: Bu çalışmada, pasif ve aktif akış kontrol metotları birlikte kullanılarak bir dairesel silindir etrafındaki akış manipüle edilmiştir. Deneyler dairesel silindirin çapına bağl (D) Reynolds sayısının 4000 ve 10000 olduğu değerlerde rüzgâr tünelinde gerçekleştirilmiştir. Pasif akış kontrol metodu olarak 3.75D uzunluğa sahip ayırıcı plaka seçilmiştir. Aktif akış kontrol metodu elemanı olarak ise plazma aktüatörler seçilmiş̧ir ve dairesel silindirin $\pm 90^{\circ}$ konumuna yerleştirilmiştir. Aktif ve pasif akış kontrol yöntemleri birlikte kullanılarak, bu yöntemleri ayrı ayrı kullanılmasına göre daha büyük bir azalma elde edilmiştir. Reynolds sayısının 5000 ve 10000 olduğu değerler için hibrit yöntem, sürükleme katsayısında sırasıyla \%48 ve \%45 azalma sağlamıştır. Hız ölçümleri kızgın tel anemometresi kullanılarak yapılmıştır ve iz bölgesindeki hız profilleri elde edilmiştir. Akış, duman-tel yöntemi kullanılarak görselleştirilmiştir. Plazma aktüatörlü ve ayırıcı plakalı dairesel silindirin iz bölgesinin sade silindire ve ayırıcı plaka kullanılan silindirin iz bölgesine kıyasla daha dar bir genişliğe sahip olduğu sonuçlarla ortaya koyulmuştur. Ayrıca, spektral analizden, hibrit akış kontrol yöntemi kullanılarak girdap kopma frekansının önemli ölçüde baskılandığı gözlemlenmiştir.

Anahtar Kelimeler: Dairesel silindir, Plazma aktüatör, Ayırıcı plaka, Hibrit akış kontrol, Girdap kopma frekansı.

\section{NOMENCLATURE}

$\begin{array}{ll}A C & \text { Alternative current } \\ C_{D} & \text { Drag coefficient } \\ D B D & \text { Dielectric barrier discharge } \\ D C & \text { Direct current } \\ D & \text { Diameter of the circular cylinder }[\mathrm{mm}] \\ L & \text { length of the splitter plate }[\mathrm{mm}] \\ \mathrm{Re} & \text { Reynolds number }\left[=\mathrm{U}_{\mathrm{o}} \rho \mathrm{D} / \mu\right] \\ \mathrm{St} & \text { Strouhal number }\left[\mathrm{fD} / \mathrm{U}_{\mathrm{o}}\right] \\ U_{o} & \text { Free stream velocity }[\mathrm{m} / \mathrm{s}]\end{array}$

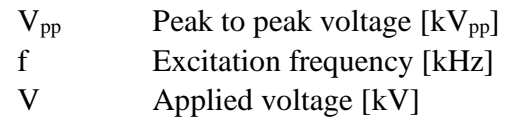

\section{INTRODUCTION}

Flow around bluff bodies receives a great deal of attention in different engineering applications. The circular cylinder is one of those bluff bodies under consideration. The separated shear layer generates vortices in the near wake region of the circular cylinder 
and vortex shedding leads to vibrations due to unsteady forces which affects the stability of the bluff bodies. In engineering applications, some flow control methods are used in order to suppress the vortex shedding and vibration, and also to reduce drag force that acts on the bluff bodies. These methods are mainly classified as active and passive control methods. The active control methods use energy in order to manipulate the flow. In recent years, the plasma actuators gathered interest as an active flow control method (Akbiyık et al., 2017; Messanelli and Belan, 2017). The plasma actuators consist of two electrodes which are separated by a dielectric material and are placed on the surface of the bluff bodies. One of the electrodes is grounded and the other one is supplied with a high voltage. The plasma actuators are easy to integrate into the model because of its simple structure which does not contain any moving parts. In the study of Sung et al. (2006), the effects of the plasma actuators on the circular cylinder to change flow separation point and flow field in the wake were investigated. Six electrode pairs were placed on the circular cylinder oppositely and directly to the flow direction. These electrode pairs were placed at $\pm 90^{\circ}$, $\pm 120^{\circ}$ and $\pm 150^{\circ}$ (angles) and the experiments were conducted at the range of Reynolds between $10^{4}$ and $4 \times 10^{4}$. Wake width of the cylinder was reduced when the exposed electrodes were placed in streamwise direction. But, the wake width was increased remarkably when the exposed electrode pairs were placed in reverse direction configuration. Jukes and Choi (2009) studied about the near-wake structure of a circular cylinder with plasma actuators at $\mathrm{Re}=15000$. They reported a reduction of lift/drag fluctuations of $70 \%$ and $32 \%$, respectively at $f_{p}$ $+=2.0$ (nondimensional frequency) and increase in lift/drag fluctuations of $87 \%$ and $7.5 \%$, respectively at $f_{p}$ ${ }^{+}=0.2$. They also emphasized that the flow separation was delayed periodically when pulsed plasma actuators were placed near the natural separation point. Tabatabaeian et al. (2012) also modified the flow around the circular cylinder by using plasma actuators. They markedly decreased pressure coefficient of a circular cylinder and this reduction led to enhancement in pressure drag coefficient by using plasma actuators. The experiments of the Thomas et al. (2008) were conducted at $\operatorname{Re}=3.3 \times 10^{4}$ in order to eliminate Kármán shedding and to reduce noise. The plasma actuators were placed on the circular cylinder at \pm 90 and \pm 135 degrees and the plasma actuators were activated as steady and unsteady.

In contrary to active control, passive control methods which are based on the principle of geometrical modifications or adding additional bodies, do not need energy input to control the flow (Güler et al., 2018). Some illustrative examples of passive control techniques are perforated fairing (Durhasan et al., 2016), a splitter plate (Akansu et al., 2004; Sarioglu, 2016; Sarioglu et al., 2016), a control rod (Akansu et al., 2011; Gim et al., 2011), helical wires (Ekmekci, 2014). Among the passive flow control methods, the splitter plate is one of the most commonly used methods. Roshko (1961) reported that the splitter plate affects the flow and it decreases drag coefficient of the circular cylinder at $\mathrm{Re}=3.5 \times 10^{6}$. Akansu et al. (2004) studied the effect of the splitter plate placed on the rear of the circular cylinder at a Reynolds number range of $8 \times 10^{3}$ to $6 \times 10^{4}$. It was shown that usage of the splitter plate on the back of the circular cylinder at different angles change the Strouhal numbers, pressure distributions and lift coefficients of the circular cylinder. Also, the circular cylinder with the splitter plate has smaller drag coefficient than the circular cylinder alone. The splitter plate, attached on a circular cylinder appears to dramatically decrease the drag coefficient (Apelt et al., 1973, Apelt and West, 1975). In the study of Apelt and West (1975), different splitter plate lengths were used $(\mathrm{L} / \mathrm{D} \leq 2 \mathrm{D})$. Apelt et al. (1973) changed the L/D ratio from 2 to 7 at Reynolds numbers between $10^{4}$ and $5 \times 10^{5}$. The increasing $\mathrm{L} / \mathrm{D}$ ratio from $2 \mathrm{D}$ to $5 \mathrm{D}$ is reported to have affected the drag and vortex shedding. However, when the ratio of $\mathrm{L} / \mathrm{D}>5$, there was no change in the vortex shedding and drag coefficient. In the study of Cimbala and Leon (1996), both the circular cylinder with rigidly fixed splitter plate at 0 degree and circular cylinder with rotatable splitter plate were tried at $2 \times 10^{4}<\mathrm{Re}<8 \times 10^{4}$ in order to obtain drag forces. The splitter plates with different lengths (between 0 and 5D) were attached behind the circular cylinder. Both rotatable splitter plates and fixed ones at an angle of 0 degrees provided the same drag reduction. Nakamura (1996) examined five different bluff body models with splitter plate with lengths varying from 0 to $15 \mathrm{D}$ for the Reynolds number between 300 and 5000. Also, Strouhal number and pressure coefficient change against L/D ratio were investigated at Reynolds number of 1600 and 5300.

In this study, a hybrid flow control method is presented aiming to achieve better flow control such as drag reduction and flow structure manipulation. The hybrid flow control methods could be considered as the combinations of passive-passive, passive-active (Rezazadeh, 2013), and active-active methods. In this study, combination of passive and active methods was chosen. For this purpose, the splitter plate is used for passive flow control and the dielectric barrier discharge (DBD) plasma actuators are used for active control. It is shown that combining the flow control methods reduced the drag coefficient of the circular cylinder far more effectively. Furthermore, the flow structure was changed and the wake region was narrowed far more effectively.

\section{EXPERIMENTAL SETUP}

The experiments were conducted in an open-suction type wind tunnel. The wind tunnel has a $570 \mathrm{~mm}$ x $570 \mathrm{~mm}$ x $1000 \mathrm{~mm}$ test section and a $6.25: 1$ contraction ratio. The plexi-glass test model consists of four parts. First one is a smooth circular cylinder with $40 \mathrm{~mm}$ diameter (D) and $4 \mathrm{~mm}$ (wall) thickness. The second one is a two circular end plates with $280 \mathrm{~mm}$ diameter and with a spanwise distance of $400 \mathrm{~mm}$ between them. The circular cylinder is placed at $100 \mathrm{~mm}$ offset from the end plate circle centers. The third one is a $10 \mathrm{~mm}$ diameter chrome rod strut which is used to connect the test model to a load cell. 
The last part is the plexi-glass splitter plate with $3 \mathrm{~mm}$ thickness. The visualization of the test model is given in Fig. 1.

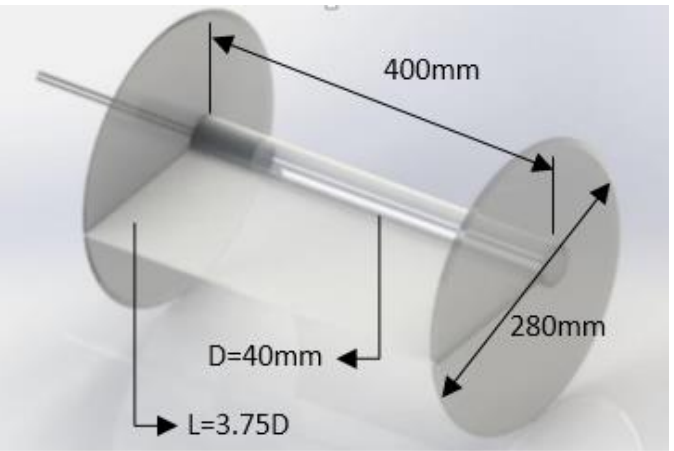

Figure 1. Schematic view of the test model

It is reported that the increase in splitter plate length leads to reduction in the drag of the circular cylinder (Cimbala and Leon, 1996). Thus, the splitter plate length in our study was chosen to be $3.75 \mathrm{D}$ to achieve streamlined body. The splitter plate was placed on the center axis of the rear side of the circular cylinder. The plasma actuators were used as active flow control component. In order to produce plasma, the embedded electrode was grounded and the exposed one was connected to high voltage. The plasma actuators were placed along the test model and had a thickness of $0.06 \mathrm{~mm}$. Kapton tape dielectric material was placed between these two electrodes. The symmetrical actuator pair was placed on the cylinder with $\theta= \pm 90^{\circ}$ angle (with respect to the splitter plate, where positive values correspond to a counter clockwise direction). Since forcing with plasma actuators is most effective just before the separation point. Significant effects were observed when the plasma actuators located very close to the laminar separation point (Jukes and Choi, 2009). Fig. 2 shows the schematic of the test model and electrodes.

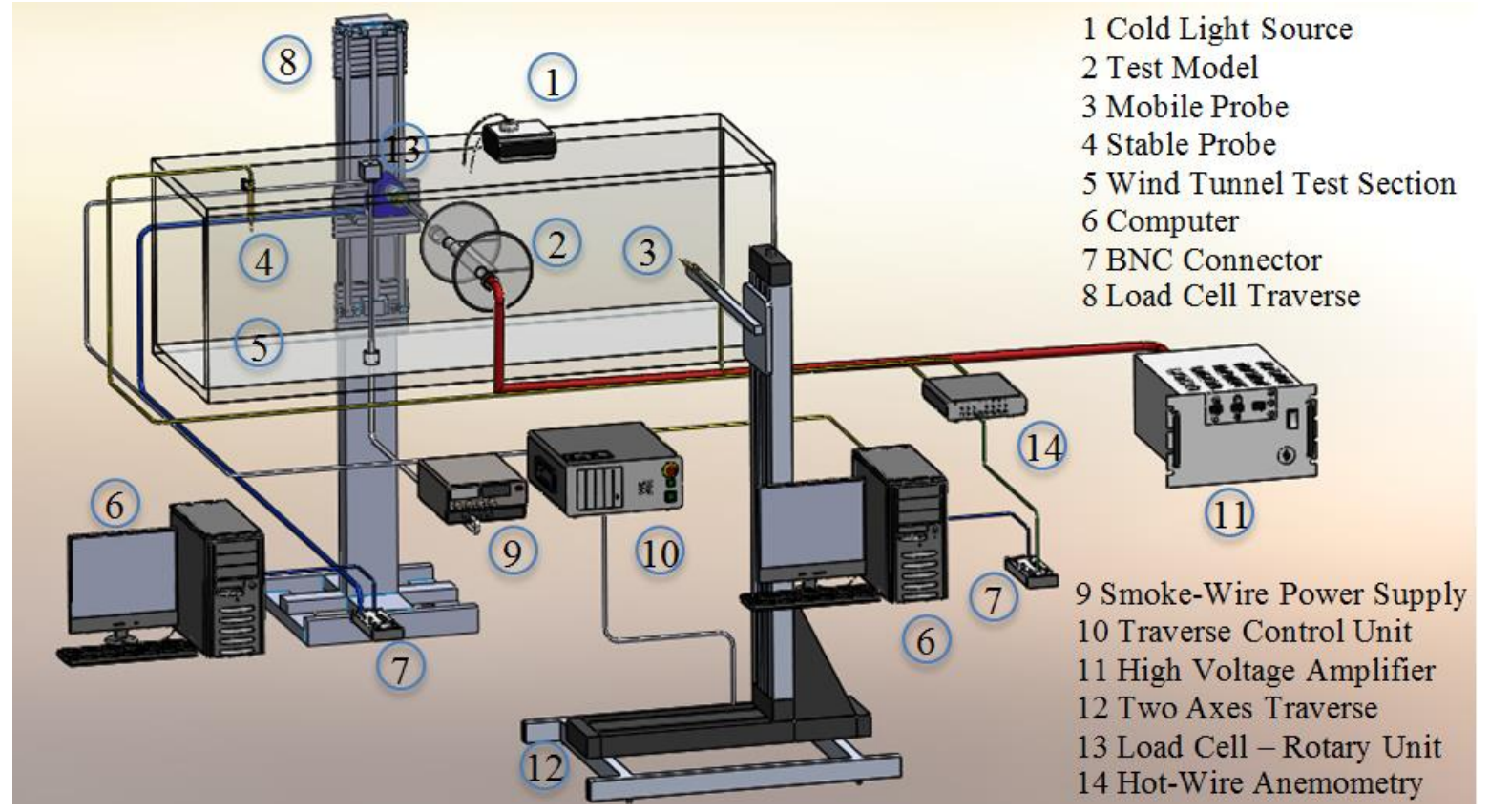

Figure 3. The schematic diagram of experimental setup

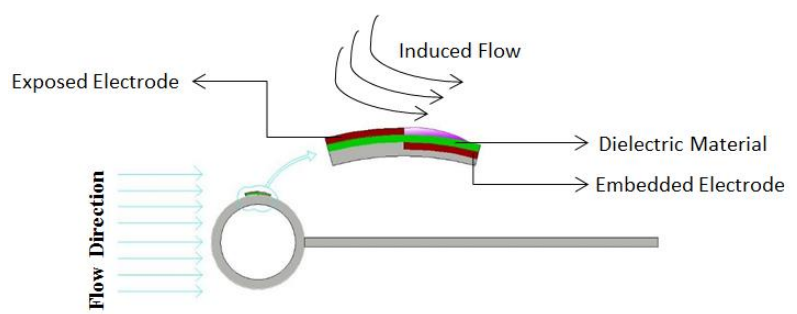

Figure 2. Schematic of the model and flow control components.

The actuators were driven with the sinusoidal signal TREK 20/20C-HS model high voltage power amplifier. In order to produce plasma, applied voltage and frequency were varied from 4.8 to $10 \mathrm{kV}_{\mathrm{pp}}$ and from 3.5 $\mathrm{kHz}$ to $4.5 \mathrm{kHz}$, respectively. The solid blockage ratio was $5 \%$ in the open circuit suction type wind tunnel. There is no correction if blockage ratio was smaller than $6 \%$ at $10^{4}<\operatorname{Re}<5 \times 10^{4}$ (Apelt et al., 1973).

The velocity profile and vortex shedding frequency measurements were made by using Dantec Multichannel CTA 54N81 model hot-wire anemometer. During the experiments, 2 hot-wire probes were used as shown in Fig. 3. One of them was moveable probe (55P11), and the other one was fixed probe (55P16) used for measuring the free stream velocity. The moveable probe was positioned at 9D distances behind the circular cylinder. The velocities were normalized by dividing to the velocity values taken from the fixed probe. When the plasma was on, the velocity measurements were conducted at $2 \mathrm{kHz}$ sampling frequency and 10000 velocity values were taken from each point. For the case without plasma, 16384 velocity values were taken from each point with the same sampling frequency. 


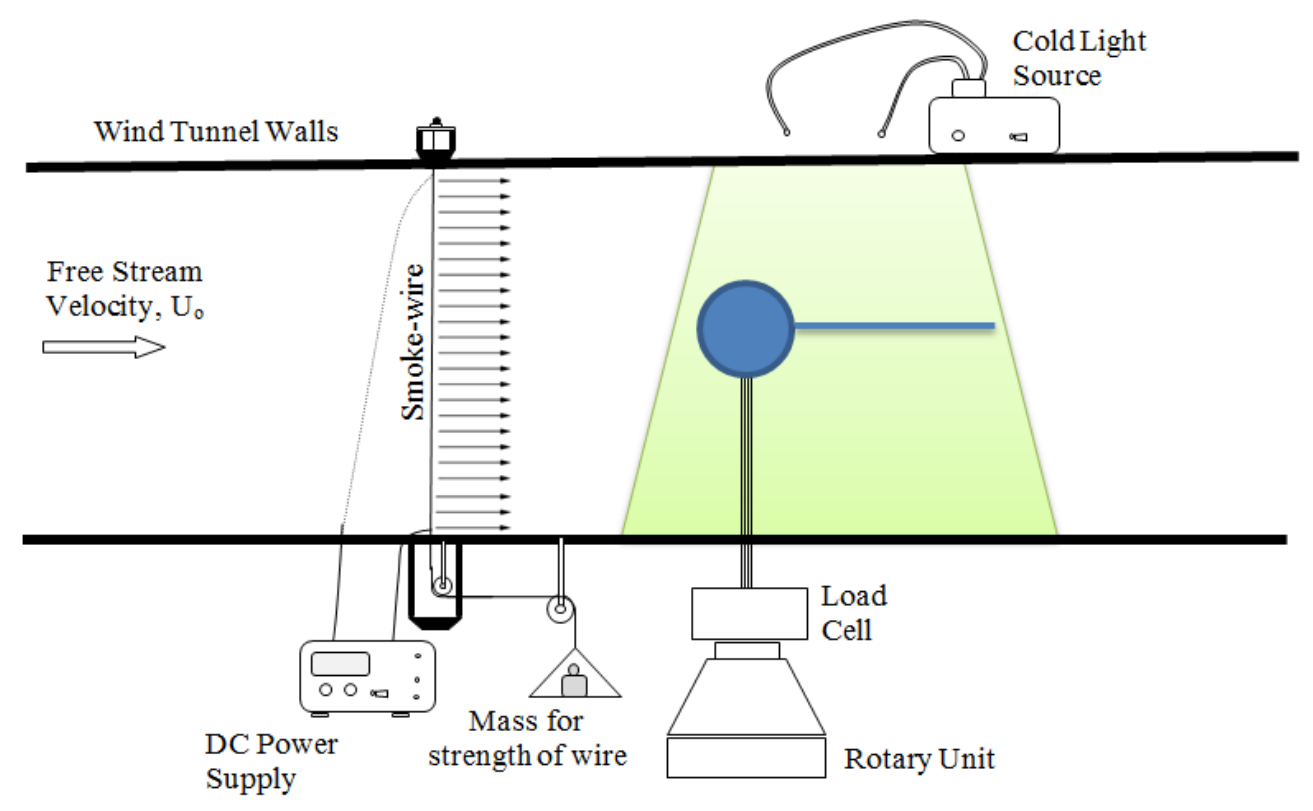

Figure 4. Schematic of smoke-wire method.

The test section of the wind tunnel consists of plexiglass and has a divergence angle of 0.3 degrees to keep the static pressure constant between the test section inlet and outlet. Free-stream turbulence intensity is about $0.5 \%$ in the working Reynolds number range.

In order to measure the drag forces, ATI model six-axis load cell was used. This device was integrated on a computer controlled rotary unit. The measurements were taken at $100 \mathrm{~Hz}$ frequency and 50 values were averaged. For each measurement, 80 values were acquired in 40 seconds and each measurement was repeated 3 times for all parameters tested. Therefore, repeatability of the experiment was tested and reduction in error margin was aimed. The drag forces acting on the other components of the model, end-plates and the rod strut were extracted from the total drag force. As a result, the net drag force acting on the circular cylinder was calculated.

The uncertainty in the force measurement system was estimated to be less than $\pm 5 \%$. The uncertainties of the load cell and data acquisition card were calculated in order to determine the uncertainty of the force measurements. The uncertainty in velocity measurement by the hot-wire anemometer was calculated to be less than $\pm 5.2 \%$. To observe the flow around the circular cylinder, a smoke-wire method was used. Fig. 4 shows the schematic of the smoke-wire flow visualization method. A DC power supply was used to produce smoke from liquid paraffin.

\section{RESULTS AND DISCUSSION}

The flow separation from the circular cylinder surface was manipulated by using plasma actuators. Flow visualization images of the experiments are given in Fig. 5 and Fig. 6 for Reynolds number of 4200. The voltage and frequency were $6.5 \mathrm{kV}_{\mathrm{pp}}$ and $3.5 \mathrm{kHz}$, respectively. As seen in Fig. 5, the plasma actuator without splitter plate caused a smaller vortex formation region and the plasma actuator delayed the flow separation point to the rear side of the circular cylinder. In the case of splitter plate without plasma actuators (Fig.6), the vortex shedding region was extended towards the backside. By combining both flow control methods (plasma actuators and splitter plate), the width of the wake behind the circular cylinder was reduced (even further).
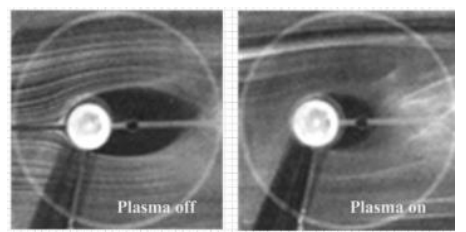

Figure 5. The effect of the plasma actuator on the flow visualization around the circular cylinder without splitter plate
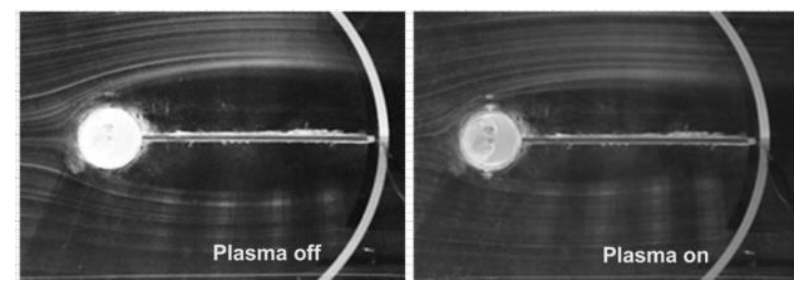

Figure 6. The effect of the plasma actuator and splitter plate on the flow visualization around the circular cylinder

The applied voltage is one of the most important parameters of the plasma generation. In this study, the effect of the applied voltage was investigated at $\mathrm{Re}=$ 4200. The applied signal frequency was a constant 3.5 $\mathrm{kHz}$, the applied plasma voltage had 3 values, $4.8 \mathrm{kV}$, $6.0 \mathrm{kV}$, and $7.2 \mathrm{kV}$. Fig. 7 shows graphically the effect of the applied voltage on the ability of the plasma actuators to manipulate the wake region of the circular cylinder. For the lowest applied voltage value $(4.8 \mathrm{kV})$, the ability of the plasma to control the flow around the circular cylinder was observed to be weak. But, an increase in the applied voltage gave rise to narrower wake 
region. It is known that a narrow wake region cause reduction in the drag force by changing the base pressure. The narrowest wake region was obtained at $7.2 \mathrm{kV}$ and wake region width (y/D) was reduced from \pm 2 to \pm 1 .

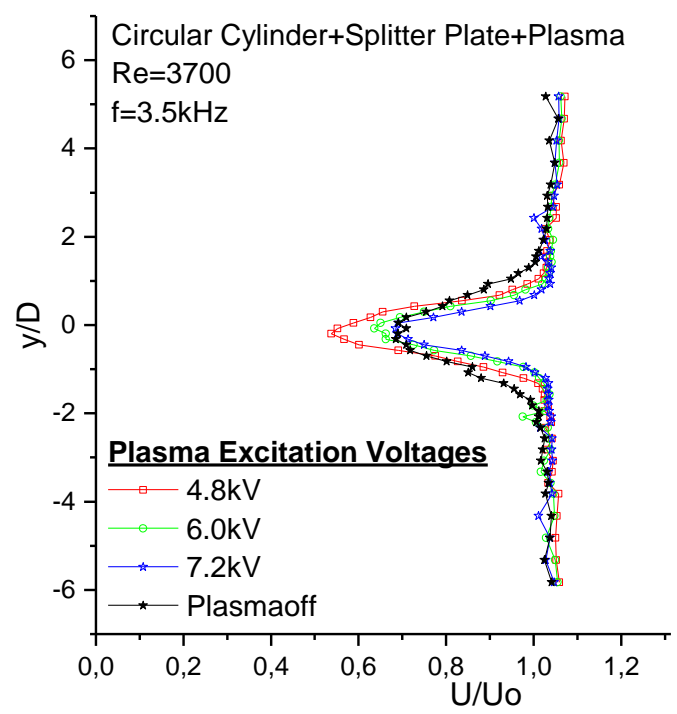

Figure 7. In case of the hybrid flow control method, the wake region analysis of the circular cylinder for the applied voltages $(4.8 \mathrm{kV}, 6.0 \mathrm{kV}, 7.2 \mathrm{kV})$ at $\mathrm{Re}=4200$.

Fig. 8 shows the wake region profiles for bare circular cylinder, circular cylinder with splitter plate, and circular cylinder with plasma actuator and splitter plate at $\operatorname{Re}=4200$. In this case, the applied voltage and signal frequency are kept constant at $7.2 \mathrm{kV}_{\mathrm{pp}}$ and $3.5 \mathrm{kHz}$, respectively. The flow separation started earlier for the bare cylinder and the vortex shedding was observed at a shorter distance. The width of the wake was dramatically reduced when the hybrid control method was used. The splitter plate augmented the vortex formation length (distance between the center of the circular cylinder to the end of the splitter plate). The location of the flow separation delayed on a rear position. In addition to this, thinner wake region of the circular cylinder is observed. This can be seen easily from the flow visualization in Fig. 6. A spectral analysis was made to obtain the vortex characteristics for the bare circular cylinder the cylinder with splitter plate, and the hybrid flow control model. Fig. 9 shows the velocity time-histories and their power spectrums which were recorded at $\mathrm{Re}=4200$ by using the moveable probe placed at $x / D=9$ and $y / D=0.9$. In Fig. 9a, the vortex shedding is regular and the timehistory of the bare circular cylinder has periodic fluctuations due to regular vortex shedding. On the other hand, the vortex shedding frequency decreases and bigger vortex formation length occurs for the circular cylinder with splitter plate.

The vortex shedding was almost prevented and random weak vortices occurred when the plasma actuators were activated. According to the instantaneous velocity distribution and the power spectrum analysis in Fig 9, the amplitude range of the velocity fluctuating values for the circular cylinder with splitter plate and the base circular cylinder (varied between 0.5 and 2.5) were suppressed by the using plasma actuators. In the case of the circular cylinder with the plasma actuator and the splitter plate, the velocity amplitude range was attenuated between 1 and 2. Moreover, this disappearance of fluctuations in the velocity time history indicates that regular and strong vorticities are inhibited. Therefore, no pick values are observed in the frequency domain of the power spectrum analysis. When the plasma was activated, the vortex shedding was suppressed. Moreover, no peak value was observed for the vortex shedding frequency because of the random vortex shedding. In the study of Jukes and Choi, (2009), the vortex shedding was also suppressed when the surface plasma was placed on the separation point.

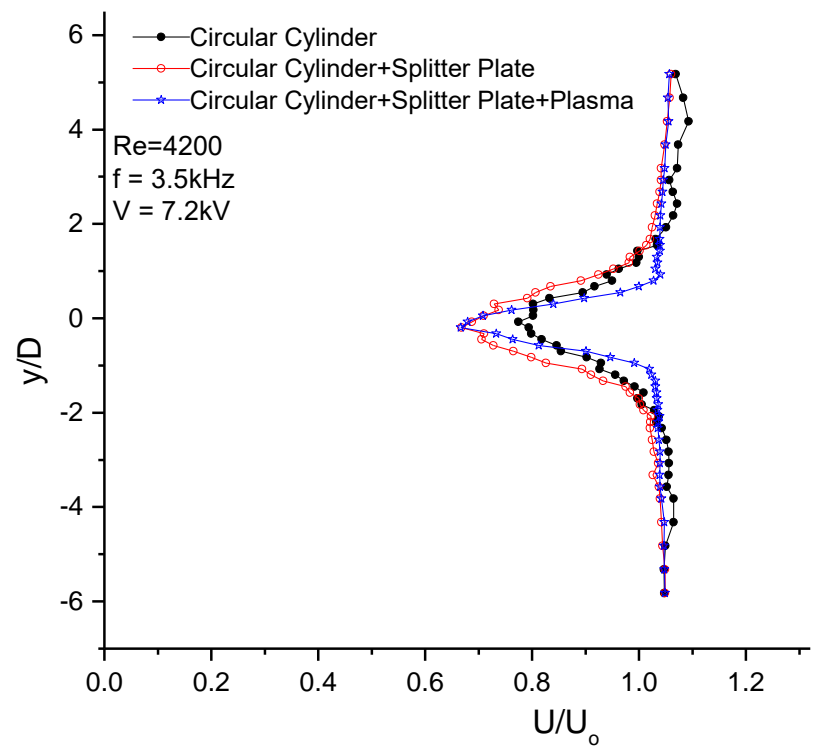

Figure 8. The wake region analysis for different flow control method.

Fig. 10 shows the effect of the applied voltage for the hybrid flow control method at $\operatorname{Re}=4200$. When the plasma was off, the vortex shedding behind the circular cylinder with the splitter plate occurred periodically. The vortex shedding started to become disordered when the plasma was on. The regular vortex shedding frequency was prevented when the applied plasma voltage was $4.8 \mathrm{kV}$. Increasing the voltage value to $6 \mathrm{kV}$, random and small size vortices did not cause a dominant peak at the spectral area. Moreover, the irregular vortices were suppressed further when the voltage was increased gradually.

The drag coefficients of the four different cases of the test models were calculated based on the force measurement results. Table 1 shows the drag coefficients at $\operatorname{Re}=5000$ and 10000. In the active flow control method, the drag reduction was increased when the applied voltage was increased. But, the effect of the active flow control method was decreased with an increasing Reynolds number. The hybrid flow control method reduced the drag coefficient of the circular cylinder more than the case of passive or active control methods alone. 
$\underline{\mathrm{Re}=4200 \text {; Probe Placement: }(\mathrm{x} / \mathrm{D}=9 ; \mathrm{y} / \mathrm{D}=-0.9)}$

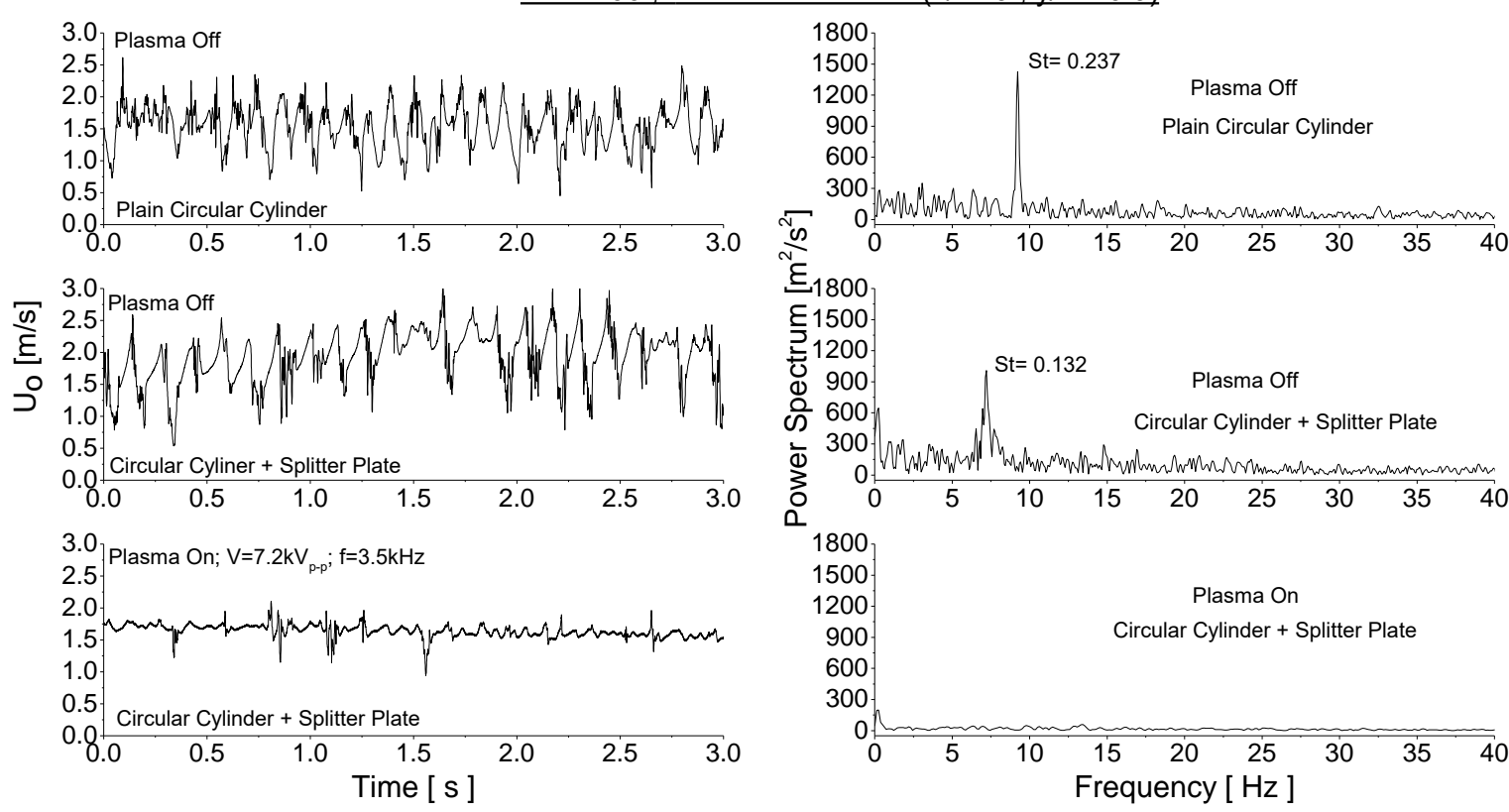

Figure 9. The time history and power spectrum analysis for the hybrid, active and passive flow control method at $\mathrm{x} / \mathrm{D}=9$ and $\mathrm{y} / \mathrm{D}=0.9$ probe positions.

Re:4200

Probe Placement: $(x / D=9 ; y / D=-0.9)$
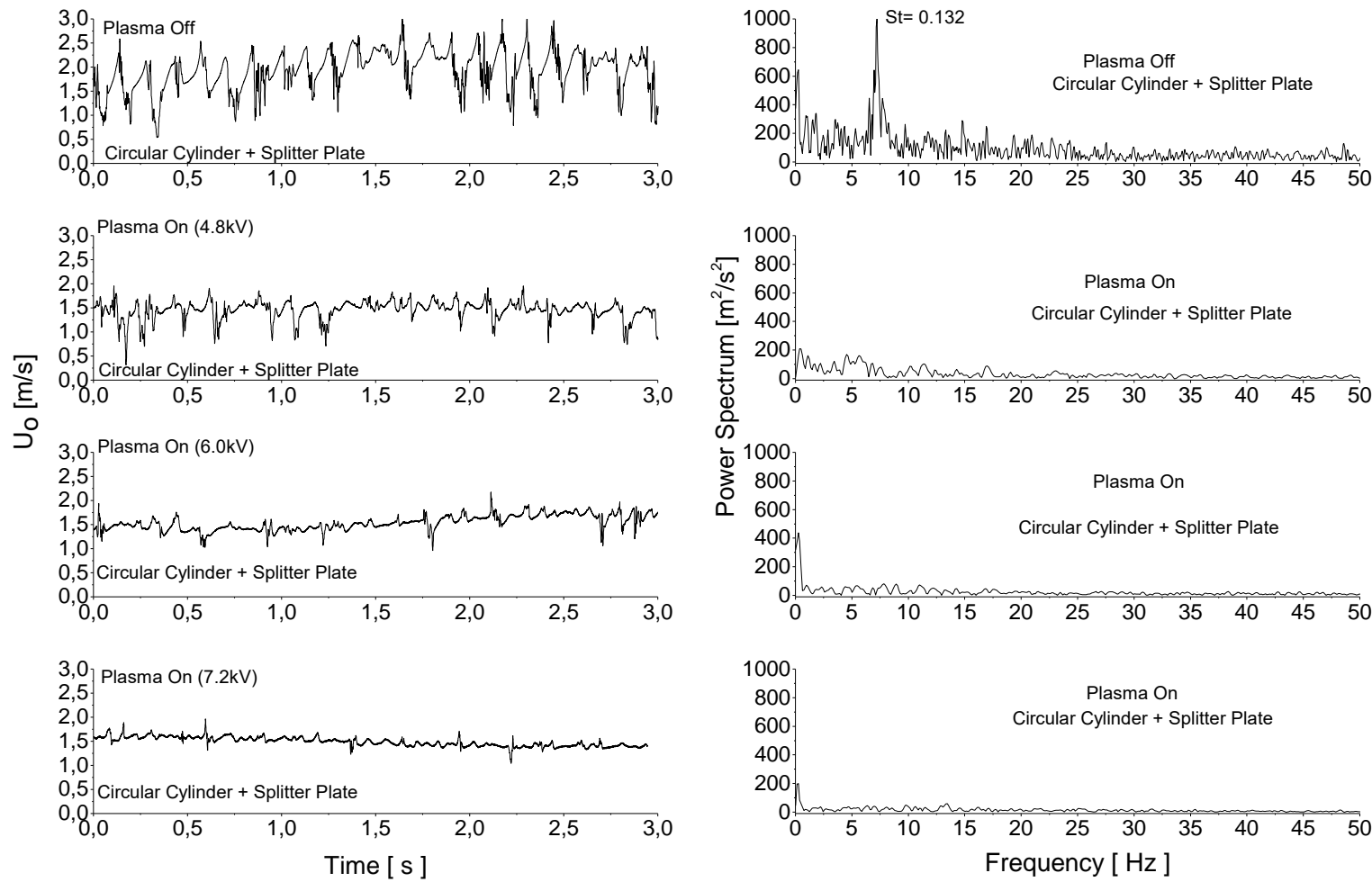

Figure 10. The time history and power spectrum analysis for the hybrid and passive flow control method at $\mathrm{x} / \mathrm{D}=9$ and $y / D=0.9$ probe positions

In the case without a splitter plate, it is observed that the drag coefficient of the circular cylinder with the plasma actuator at an applied voltage of $10 \mathrm{kV}$ was less than the drag coefficient of the bare circular cylinder for all Reynolds numbers. The active flow control method was more effective than passive flow control at $\mathrm{Re}=5000$ when the applied voltage increased. The drag coefficient of the circular cylinder decreases from 1.24 to 0.73 when using active control with an applied volt of $10 \mathrm{kV}$. However, when the Reynolds number increased to 
10000, the splitter plate behind circular cylinder gave better results than the plasma actuator. The splitter plate decreases the drag coefficient to 0.90 while the plasma actuator decreases it from 1.35 to 0.98 . In case of the hybrid flow control at Reynolds numbers of 5000 and 10000 , the reduction in drag coefficient was calculated to be about $48 \%$ and $45 \%$, respectively. For a Reynolds number of 5000, the passive flow control method reduced the drag coefficient from 1.24 to 0.84 . By adding the effect of the active control, its value dropped down to 0.65 .

Table 1. Variation of the coefficient of the test models depending on Reynolds numbers and the applied voltage.

\begin{tabular}{|c|c|c|c|c|}
\hline \multirow{2}{*}{$\begin{array}{l}\text { Model } \\
\text { type }\end{array}$} & \multirow{2}{*}{$\begin{array}{c}\text { Supply } \\
\text { voltage }[\mathrm{kV}]\end{array}$} & \multicolumn{3}{|c|}{ Reynolds Number } \\
\hline & & 5000 & 10000 & \\
\hline ○ & Plasma Off & 1.24 & 1.35 & \\
\hline & 6 & 1.13 & 1.35 & U \\
\hline & 8 & 0.76 & 1.13 & $\overrightarrow{\tilde{e}}$ \\
\hline & 10 & 0.73 & 0.98 & $\overline{0}$ \\
\hline & Plasma Off & 0.84 & 0.90 & 8 \\
\hline & 6 & 0.74 & 0.84 & $U_{0}$ \\
\hline & 8 & 0.70 & 0.76 & 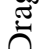 \\
\hline & 10 & 0.65 & 0.74 & \\
\hline
\end{tabular}

\section{CONCLUSIONS}

The presented study proposes a novel flow control approach based on the splitter plate and DBD plasma actuator used simultaneously. The proposed hybrid flow control method has been shown to have greater effect in order to control of the flow around the circular cylinder. A splitter plate was chosen as passive flow control device and its length was chosen to be 3.75D. Plasma actuators were placed on the circular cylinder at a position of $\pm 90^{\circ}$ as active flow control device.

With the effect of the splitter plate, the vortex forming region was elongated to a point far from the rear side of the circular cylinder and separation shear layers from the surface of the cylinder gave rise to the narrow wake region. When the plasma was activated, the vortex shedding was suppressed. The use of plasma actuators prevents the natural vortex shedding from the bluff body due to the reattachment of the separated flow. In addition, when the plasma actuators are activated, the induced flow generates a cycle in which air are ionized. With the help of induced flow, the shear layer which tends to separate from the surface has been continued to flow on the surface of the cylinder. Thus, flow separation occurs at a more rear position of the cylinder which generates smaller, weaker and random vorticities. Moreover, no peak value was observed for the vortex shedding frequency because of the random and smaller vortex shedding. The usage of the plasma actuators delays the separation point. Furthermore, the wake width of the circular cylinder became narrower when the plasma voltage was increased. At the highest plasma voltage, the wake region width was decreased approximately $50 \%$ by suppressing the separated shear layer from the circular cylinder. However, no effect was observed when the plasma excitation frequency was changed within our experimental range.

The drag force was also reduced significantly by means of the narrowing wake width when the plasma voltage increased (Table 1). It is observed that the hybrid flow control method is far more effective than just using either the passive or active method alone in an attempt to reduce drag coefficient. The reduction in drag of the circular cylinder with plasma actuator was not much effective compared to the bare circular cylinder when the Reynolds number increased. Therefore, the applied plasma voltage should be increased for higher Reynolds numbers. In this study, the reduction in the drag force was approximately $48 \%$ for the studied ranges of the voltages.

\section{ACKNOWLEDGEMENTS}

The authors would like to acknowledge the financial support of this work by the Scientific and Technological Research Council of Turkey (TUBITAK) under the Contract Number of 110M056. The authors also thank the rest of the project team and Prof. Dr. Hakan YAVUZ for their assistance in the performing of the study.

\section{REFERENCES}

Akansu Y. E., Bayindirli C. and Seyhan M., 2016, The Improvement of Drag Force on a Truck Trailer Vehicle By Passive Flow Control Methods, Isl Bilim. Tek. Derg./Journal Of Thermal Science And Technology, 36(1), 133-141.

Akansu Y. E., Ozmert M., and Firat E., 2011, The effect of attack angle to vortex shedding phenomenon of flow around a square prism with a flow control rod, Isl Bilim. Tek. Derg./Journal of Thermal Science And Technology, 31(1), 109-120.

Akansu Y. E., Sarioglu M., and Yavuz T., 2004, Flow around a rotatable circular cylinder-plate body at subcritical Reynolds numbers, AIAA J., 42(6), 1073-1080.

Akbıyık H., Akansu Y. E., and Yavuz H., 2017, Active control of flow around a circular cylinder by using intermittent DBD plasma actuators, Flow Meas. Instrum, $53,215-220$

Apelt C. J. and West G. S., 1975, The effects of wake splitter plates on bluff-body flow in the range $10^{4}$ $<\mathrm{R}<5 \times 10^{5}$, Part 2, J. Fluid Mech., 71(1), 145-160.

Apelt C. J., West G. S., and Szewczyk A. A., 1973, The effects of wake splitter plates on the flow past a circular cylinder in the range $10^{4}<\mathrm{R}<5 \times 10^{4}, \mathrm{~J}$. Fluid Mech, 61(1), 187-198.

Cimbala J. M., and Leon J., 1996, Drag of freely rotatable cylinder/splitter-plate body at subcritical Reynolds number, AIAA J., 34(11), 2446-2448. 
Durhasan T., Aksoy M. M., Pinar E., Ozkan G. M., Akilli H., and Sahin B., 2016, Vortex street suppression of a circular cylinder using perforated semi-circular fairing in shallow water, Exp. Therm. Fluid Sci., 79, 101-110.

Ekmekci A., 2014, Circular cylinders fitted with smallscale straight and helical wires: A comparative study on the wire-induced critical effects. Exp. Therm. Fluid Sci., $53,179-189$.

Gim O. S., Kim S. H., and Lee G. W., 2011, Flow control behind a circular cylinder by control rods in uniform stream. Ocean Eng., 38(17-18), 2171-2184.

Güler A. A., Seyhan M., and Akansu Y. E., 2018, Effect of signal modulation of dbd plasma actuator on flow control around NACA 0015. Isi Bilim. Tek. Derg./ Journal of Thermal Science and Technology, 38(1), 95105.

Jukes T. N. and Choi K.S., 2009, Active control of a cylinder wake using surface plasma, In IUTAM Symposium on Unsteady Separated Flows and their Control, (pp. 539-550), Springer.

Jukes T. N. and Choi K.S., 2009, Flow control around a circular cylinder using pulsed dielectric barrier discharge surface plasma. Phys. Fluids, 21(8), 84103.

Messanelli F., and Belan M., 2017, A comparison between corona and DBD plasma actuators for separation

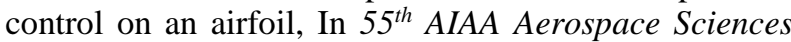
Meeting.

Nakamura Y., 1996, Vortex shedding from bluff bodies with splitter plates, J. Fluids Struct., 10(2), 147-158.
Reza-zadeh S., 2013, Investigation of fluid flow around a cylinder with EHD actuation on inclined plates behind the cylinder, In Proceedings of the 2013 International Conference on Applied Mathematics and Computational Methods in Engineering.

Roshko A., 1961, Experiments on the flow past a circular cylinder at very high Reynolds number, J. Fluid Mech., 10(03), 345-356.

Sarioglu M., 2016, Control of flow around a square cylinder at incidence by using a splitter plate, Flow Meas. Instrum., 90(462), 1-21.

Sarığlu M., Seyhan M., and Akansu Y. E., 2016, Aerodynamic forces acting on a circular cylinder with splitter plate at incidence, KSÜ. Müh. Bil. Derg./Kahramanmaras Sutcu Imam University Journal of Engineering Sciences, 19(3), 1-6.

Sung Y., Kim W., Mungal M.G., and Cappelli M.A., 2006, Aerodynamic modification of flow over bluff objects by plasma actuation, Exp. Fluids, 41(3), 479-486.

Tabatabaeian S., Mirzaei M., Sadighzadeh A., Damideh V., and Shadaram A., 2012, Experimental investigation of the effects of various plasma actuator configurations on lift and drag coefficients of a circular cylinder including the effects of electrodes, Chinese J. Aeronaut., 25(3), 311-324.

Thomas F. O., Kozlov A., and Corke T. C., 2008, Plasma Actuators for Cylinder Flow Control and Noise Reduction, AIAA J., 46(8), 1921-1931.

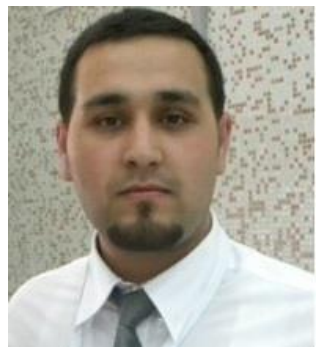

Hürrem AKBIYIK, received his B.Sc. degree and M.Sc. degree in Mechanical Engineering from Niğde University in 2012 and 2014, respectively. He is currently a PhD student at Çukurova University, where he also works as research assistant. His research interests include plasma actuators for flow control and flow control applications.

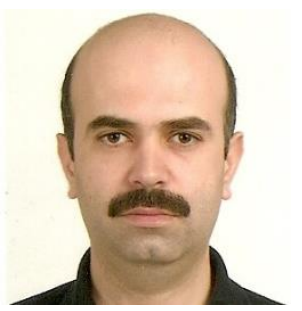

Yahya Erkan AKANSU, received his B.Sc. degree in Mechanical Engineering from Erciyes University in 1993, M.Sc. degree and Ph.D. degree from Karadeniz Technical University in 1998 and 2004, respectively. He currently works as Professor in Mechanical Engineering Department of Niğde Ömer Halisdemir University. His research interests include active and passive aerodynamic flow control applications. 